\title{
Sanitation Behavior and Risk of Stunting: Understanding the Discourse of a Public Service Announcement
}

\section{Perilaku Sanitasi dan Risiko Stunting: Memahami Wacana pada Sebuah Iklan Layanan Masyarakat}

\author{
Silva Liem ${ }^{1}$, Rustono Farady Marta ${ }^{2}$, Hana Panggabean ${ }^{1}$ \\ ${ }^{1}$ Faculty of Psychology, UNIKA Atma Jaya, J1. Jend. Sudirman No. 51, Karet \\ Semanggi, Jakarta 12930, Indonesia \\ ${ }^{2}$ Magister of Communication Science, Universitas Bunda Mulia, Jl. Lodan Raya No. 2, \\ Jakarta 14430, Indonesia \\ *Corresponding author, e-mail: silva.liem@gmail.com
}

\begin{abstract}
District Health Office of North Lombok Regency is developed a Public Service Announcement (PSA) to dealing with high stunting prevalence, by inform people about poor sanitation behavior and stunting. Using SaniFOAM framework, this study aimed to critically analyzed the sanitation behavior, its setting, narratives, images, conversations conveyed by the PSA and their intertextuality with socio-cultural background of the rural society, to see if it's an effective communication media in advocating public to stop open defecation. Fairclough's Critical Discourse Analysis used to identify what sanitation behavior to change; social norms including potential sanctions or enforcement leading to behavior change; required knowledge, and sources of social support to adopting healthier behavior; and to realize the individual and community attitudes, and values as drivers for the change. The result indicated handwashing was not reminded; believing in shaman allowed them to spread knowledge and motivate improved attitudes toward environmental health.
\end{abstract}

Keywords: Fairclough, Stunting, SaniFOAM, Public Service Announcement.

\begin{abstract}
Abstrak
Dinas Kesehatan Kabupaten Lombok Utara membuat Iklan Layanan Masyarakat (ILM) untuk menghadapi tingginya kasus stunting, dengan menyampaikan informasi tentang perilaku sanitasi yang buruk dan kaitannya dengan stunting. Menggunakan kerangka SaniFOAM, kajian ini berusaha menganalisis secara kritis perilaku sanitasi, konteks, narasi, gambar, percakapan yang disajikan dalam ILM, serta keterkaitannya dengan latar belakang sosial budaya masyarakat pedesaan, dengan tujuan mengkaji sejauh mana ILM menjadi media komunikasi efektif dalam mengadvokasi masyarakat agar berhenti buang air besar sembarangan. Analisis Wacana Kritis Fairclough digunakan untuk mengidentifikasi perilaku sanitasi yang perlu diubah; norma sosial termasuk penegakan serta sanksi menuju adopsi perilaku baru; pengetahuan dan sumber dukungan untuk melakukan perilaku yang lebih sehat; dan memahami sikap dan nilai individu maupun masyarakat sebagai dasar perubahan perilaku. Hasil kajian ini menunjukkan bahwa mencuci tangan tidak menjadi fokus perilaku harus diubah; keyakinan pada dukun membuka peluang bagi mereka untuk berperan menyebarkan pengetahuan dan memotivasi sikap yang lebih sehat terhadap lingkungan.
\end{abstract}

Kata Kunci: Fairclough, Stunting, SaniFOAM, Iklan Layanan Masyarakat.

\section{Introduction}

The latest annual nutritional status survey or Nutrition Status Monitoring or 'Pemantauan Status Gizi' (PSG) discovers almost 30\% of children under five in 
Indonesia as stunted (Kementerian Kesehatan, 2018). Stunting is an indication of chronic malnutrition as a result of poor interaction of various child nutrition determinants. A child is stunted and severely stunted when its length or height is respectively less than two and three standard deviation of average height of children at same age. Furthermore, PSG reveals stunting incidence is higher in children under five $(29.6 \%)$ compare to younger group of below two-year old (20.1\%). High incidence of stunting, more than $50 \%$ in a number of districts (Kementerian Kesehatan, 2018), and lack of information about children's short posture as health issues create urgency to waken communities to stop blaming heredity as the reason for children not meeting height standard. Insufficient information about child nutrition as well as neglecting of risk factors and impact of stunting, require immediate corrective actions, especially of mothers and caregivers, in order to keep our future generation stay in competitive global economy.

Unlike body weight, height of children under five is frequently overlooked by their parents. It is easier and more visible to notice size of a child in comparison to another child at the same age or even different age. Often, we hear parents complaining " $m y$ daughter is too thin" or "he is too big". Both refer to body size or weight. On the other hand, unless excessive and affects vital organs' function, overweight to some extent is associated as healthy (Almoosawi et al., 2016). Parents with overweight or obese children tend to underestimate their children's weight (Chan and Wang, 2013 in Park, 2017), they do not refer to standard weight of corresponding age but rather looking up to maintain their own perception 'healthy weight'. In daily life, body weight indicates whether a child is healthy (Cheng et al., 2016; Remmers et al., 2014), whereas height is subject to heredity and not related to one's health status (MCA Indonesia, 2014). A child whose posture is less than average is seen to be born like that, it has nothing to do with nutrition status. A formative study involving health officers at national down to village level as well as health workers, community leaders, and parents concludes children's 'short posture' is not regarded as a health issue (MCA-I, 2015). The study also reveals most of Integrated Health Service Unit or 'Posyandu' cadres do not even aware of the term stunting.

Although indicating malnutrition, stunting is not merely brought by poor nutrition in-take alone. Danaei et al. (2016) conducted a study using data from 137 developing countries and pointed out that poor environmental health expose children under five a greater risk to experience stunting through various environmental-based diseases including diarrhea. According to Checkley et al. (2008), 25\% of stunting cases in children below two years old is associated with diarrhea. The same conclusion is confirmed by a study conducted in East Java where it is found that diarrhea and poor hygienic behavior are significantly related to stunting (Desyanti \& Nindya, 2017). When repeatedly experiences diarrhea, a child has higher possibility to be stunted.

A good environmental health covers the use of adequate sanitation facility by every household in a community, therefore eliminating fecal contamination due to one or more household defecating in the open. Spears (2013) claimed a positive relationship of open defecation and stunting, where districts with higher prevalence of open defecation reported higher prevalence of stunting. Furthermore, he predicted every $10 \%$ increase in prevalence of open defecation would result in $0.7 \%$ prevalence of stunting. Similar to open defecation, behavior of disposing used-pampers in the open also brings about similar contamination risk to environment. A study with mothers and caregivers in rural Bangladesh discovers that those who dispose their child's feces not in latrine report higher incidence of environmental enteropathy which is significantly associated with impaired growth of their children (George et al., 2016). 
Studies on early childhood bring about persistent findings that sanitation behavior is a risk factor of stunting (Danaei et al., 2016; Desyanti \& Nindya, 2017; George et al., 2016; Torlesse, Cronin, Sebayang, \& Nandy, 2016). To maintain adequate environmental health during early childhood development, communities need to pay attention to a number of measures of sanitation behavior, that include stop defecating in the open, the use of environmental-friendly latrines with anti-leak and regularly-emptied septic tanks, cleaning toilet area, and safely disposal of children feces and used pampers. In order to understand existing behavior at household and individual level and to design an effective sanitation program, the Water and Sanitation Program (WSP) developed SaniFOAM. SaniFOAM stands or Sanitation Focus, Opportunity, Ability, and Motivation covering various factors leading to sanitation behavior in a community (Devine, 2009). Departing from appropriate understanding of existing behavior, an effective intervention will be developed to replace unhealthy behavior with the healthy ones.

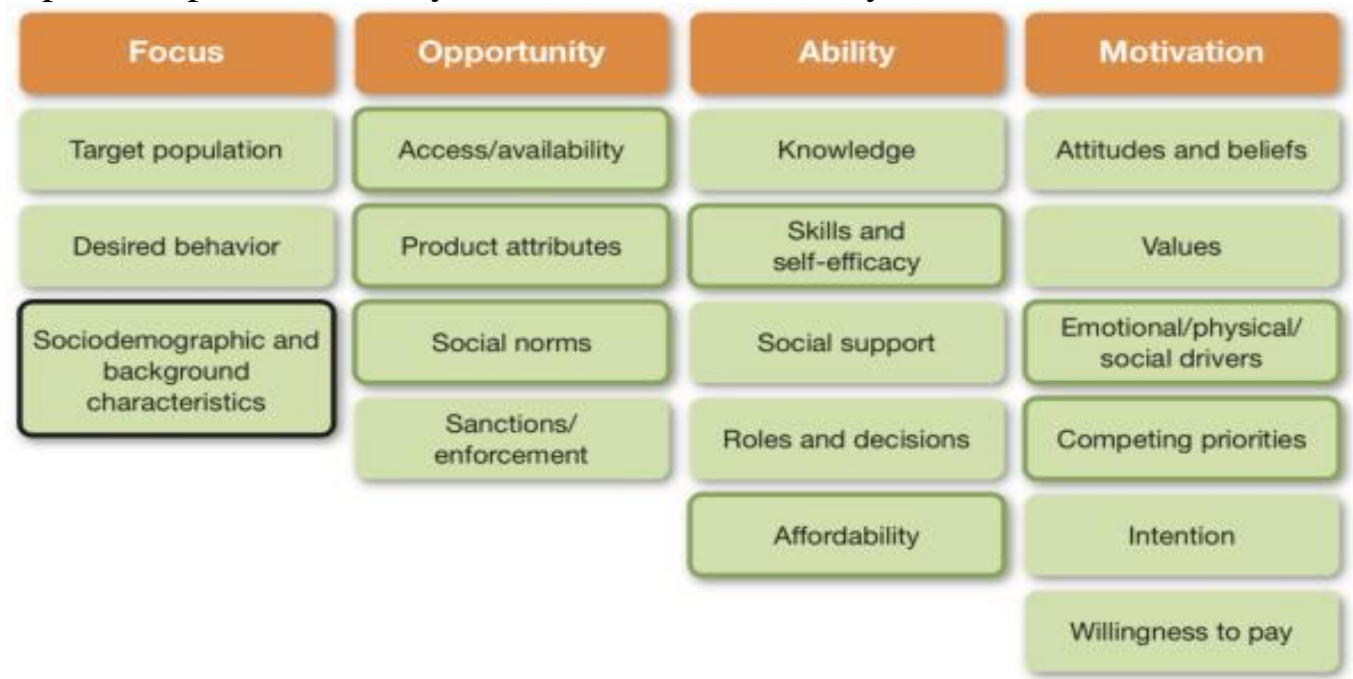

Figure 1. Key Factors found to Influence Behaviors According to the SaniFOAM Conceptual Framework. Adapted from "What Influences Open Defecation and Latrine Ownership in Rural Households?" (O’Connell, 2014)

Sanitation points at the object of sanitation behavior being observed, whereas focus refers to both targeted what behavior and who in the community group subject to behavior change intervention; opportunity sees whether sanitation products and their attributes are easily accessible in surrounding market, whether social norms support a certain behavior and what sanctions apply for any incompliances; ability aspect deals with individuals' and households' knowledge and skills to perform an adequate sanitation behavior, available social support, decision making and financial capacity that allow them to perform targeted behavior; motivation aspect analyzes attitude, beliefs, values, physical, social and emotional triggers and intentions to perform a behavior, household priorities setting and willingness to pay for recommended sanitation services. Each aspect of is explored through relevant questions such as: what behavior is subject to change and who should change (focus); how likely is the opportunity that an individual will perform a recommended behavior (opportunity); does the individual have the ability to perform the behavior (ability); and does the individual have the motivation to perform it (motivation).

The Ministry of Health Republic of Indonesia has started promoting sanitation behavior to mitigate one major risk factor of stunting, a number of District Health Office or 'Dinas Kesehatan' have also started with Public Service Announcement/PSA as an effort to improve better sanitation behavior. Discourses in PSA hold important role to 
properly convey information about stunting and to further stimulate behavior change in reducing the respective risks. As contribution to highlight the importance of environment health issues and avoid life-time consequences of stunting, this paper aims to analyze the discourse in a PSA on sanitation behavior initiated by District Health Office of North Lombok Regency. Aside from a record of $37.6 \%$ children below five are stunted in North Lombok (Kementerian Kesehatan, 2018), PSA 'Cegah Stunting - Iklan Layanan Masyarakat' produced by Pratama Pictures in 2016 is selected because of several reasons: 1) it conveys information about open defecation which represents a determinant of stunting; 2) not all community are aware of open defecation and poor Water, Sanitation and Hygiene/WASH behavior as risk factors for stunting; and 3) the context of rural village where prevalence of stunting is higher than urban area. Currently, there are no CDA (Critical Discourse Analysis) study on audio-visual format of PSA that emphasizes how WASH behavior links to stunting.

\section{Methodology}

The object of this review is a media of PSA in which poor sanitation behavior and indication of stunting are presented in a rural context. Effectiveness of the PSA may depend on the discourses presented in the media, that incorporates local context of the targeted audience. CDA is a method to analyze social issues with an emphasis on how an emerging discourse is relevant with existing social and culture arena (Fairclough, 1997 in Ulinnuha, 2015). CDA of Norman Fairclough is used as it allows multi-disciplinary point of views in analyzing the meaning of the text, images and conversation conveyed through the PSA, similar to stunting reduction which also requires multi-sectoral participation. Fairclough recognizes intertextuality concept, that is to understand the structure and organization of texts -- including images -- and their contexts (Stephen W. \& Karen A, 2009). Fairclough treats text as a component of discourse in a context, beyond merely a linguistic tool in communication. Rather, he points the importance of doing both textual to understand meaning of what is said and presented; as well as socio-cultural analysis to comprehend how community formed social practices and how they carry out the practices in daily interaction. As the consequence, Fairclough's CDA involves multidisciplinary perspective beyond communication domain. For example, to really understand the meaning of an image of a young lady screaming, we need to look beyond why she is screaming, what circumstances surrounding her, etcetera. This way, we will understand whether she is screaming out of happiness or because she is scared of something.

Following Fairclough, this paper explores the meaning behind each part of the PSA: the texts, images, and conversations, how each part has been formed, and what kind of social cultural context assumptions behind its production and acceptance by its targeted audience. Figure 2 Fairclough Discourse Analysis Framework below describes the procedures of conducting critical discourse analysis. 


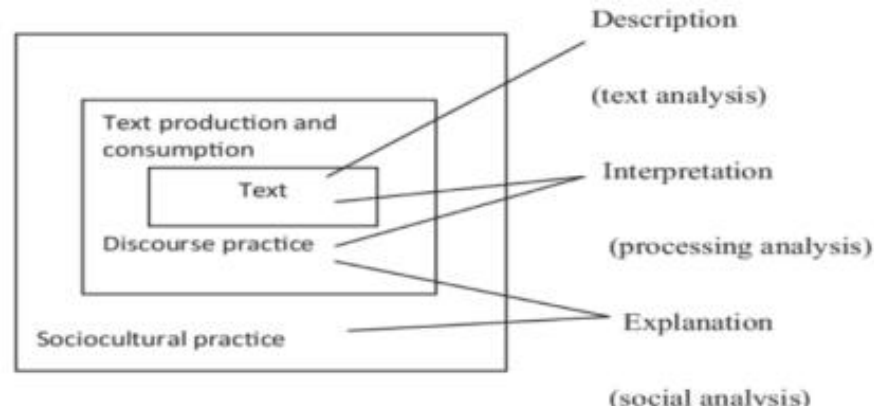

Figure 2. Diagrammatic Representation of Fairclough's Critical Discourse Analysis Framework. Adapted from 'It Is Not Easy Being Green: A Critical Discourse and Frame Analysis of Environmental Advocacy on American Television' (Omrow, 2018)

According to Ellyawati (2017), Fairclough's critical discourse analysis involves three dimensions: 1) analysis of text description; 2) analysis of process to generate interpretation; and 3) analysis of social context to generate explanation. Text analysis focus on vocabulary, grammar, semantic, tone, pitch, and linguistic features being used. Next, the process analysis aims to understand how each part of the text is being articulated to arrive at interpretation. Lastly, in social analysis, social culture element is analyzed to understand how social context - including circumstances and community structure influence the text and social interaction to eventually conclude an interpretation. Analysis of the three phases, including what are the messages, the language, how they are structured, and the figures conveying them (who say what), as well as the social setting of North Lombok, guides audience to reflect on the PSA's functionality in terms of behavior change campaign.

\section{Results and Discussion}

District Health Office of North Lombok Regency developed a PSA to promote stunting reduction by adapting more hygienic and healthy behavior. The PSA has a duration of three minutes and produced by Pratama Pictures in 2016. Division of texts is made and segmentation is titled in such a way to identify social practices with regards to open defecation, health promotion and counseling about stunting. Instead of conducting survey on the effectiveness of the PSA, this study refers to elements of a good PSA. According to Durianto in Hastuti (2013), key elements of an effective PSA include a) message as the content of the PSA, b) structure by which message is conveyed, c) format of the PSA, and d) messenger who delivers the message.

Titled as 'Cegah Stunting - Iklan Layanan Masyarakat' (Prevent Stunting - Public Service Announcement), the PSA clearly describe stunting, a term not widely-known (MCA-I, 2015). Both description and causes of stunting are narrated logically, given a particular focus on open defecation as an environment health issue and significant risk factor for stunting. The use of local language promotes its acceptance by the target audience of rural communities, at the same time reduces potential misunderstandings. In terms of structure, the storyline seems orderly presenting key messages, including an emphasis on the father's negligence on the boy's behavior to defecate in the open, and probing and confirmation about stunting by the figures. About the format, three-minute duration of audio-visual format of young productive family in daily life of earning their living and child parenting delivered in clear and unobstructed scenes might be another power of this PSA. As for the messengers, three significant actors: Head of Sub-village 
and two relevant figures of Sanitarian and Nutrition Specialist collectively bolster the overall objective to advocate behavior change in maintaining better environment health. In another CDA study, Setiawan \& Fanani, (2017) conducted representation analysis and revealed how picture of young girls had been selected to indicate them as the targeted group in preventing early marriage. Similarly, representation of young family with a suspected-stunting child, an older child defecates in the open, absence of hand-washing after defecating, and rural setting where cowsheds are just next to the family's house carefully emphasize on the targeted behavior that need to be changed.

In terms variable of behavior, analyses will be focused on social practices of defecating in the open; whereas for other variables of the setting, narratives, context, and conversation, analyses will be attributed to their intertextuality with socio cultural background of rural context.

Open defecation has been closely linked to higher risk for stunting (Danaei et al., 2016; García Cruz et al., 2017; Torlesse et al., 2016; WHO, UNICEF, \& USAID, 2015) because the human fecal substances provide pathways for flies and domestic animals to spread bacteria into residences and eating utensils and further lead to diarrhea. For children in their early childhood, frequently dealing with diarrhea increases the likelihood of stunting as they lose the nutrient they have absorbed and the depletion of their intestinal wall (Mbuya \& Humphrey, 2016).

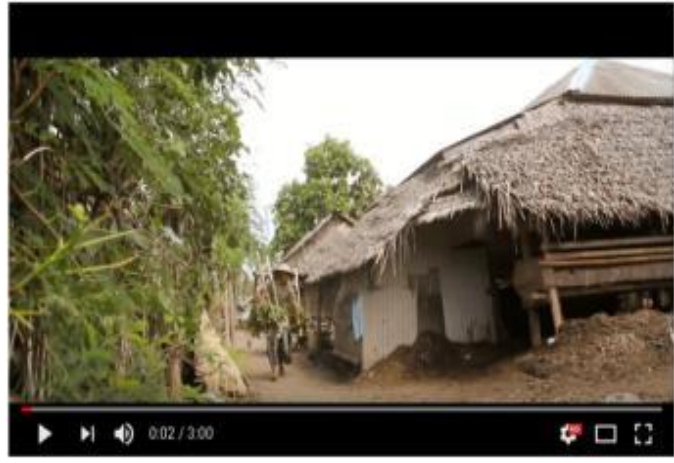

Picture 1. Rural Ambiance

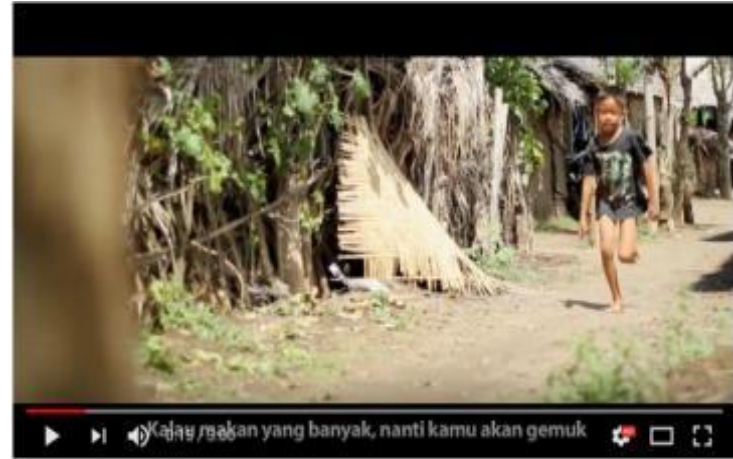

Picture 2. School-age Young Boy running freely Wearning no Underwear and Slippers

Setting of village ambiance describes rural context, houses next to cowshed (picture 1), a school-age young boy is running freely wearing no underwear and slippers does not demonstrate any shyness or disgrace (picture 2) may display ordinary scene and social norms in the village, a scene not separable to the entire discourse in the film. Just like Lombok in general, district of North Lombok has been known for its cattle industry, especially cows. It is not peculiar to find cowsheds in the middle of human settlement, even standing side-by-side. A cow has been part of the community, beyond its economic value as an asset, people in even spread cow dung to make floor in their house. It is possible that because of the value people attach to the cows that make them accept such proximity and live the norms without recognizing the hygiene consequences. Both picture 1 and picture 2 demonstrate scenes far from sanitary environment and therefore subject to change.

Four important findings from the PSA are a) defecating in the open and washing hand, b) role division in a household, c) shaman or 'dukun' as a reliable reference when it comes to child health problems, and d) community exposure of information regarding risk factors of stunting. 
Defecating in the open or disposing child's feces in the open posts the risks of environment-based disease not only for the individual doing it and her/his family, the impact of such behavior extends the risk to contaminate the surroundings (George et al., 2015). Flies, domestic pets freely coming into the house from outside surroundings may carry fecal substances left in the open and bring them into the house are examples showing the path of open defecation to environment-based diseases. Eventually, individuals whose neighbors are still practicing open defecation have to deal the same risk of environmentbased disease even though she or he safely defecates in a latrine because of the contamination.

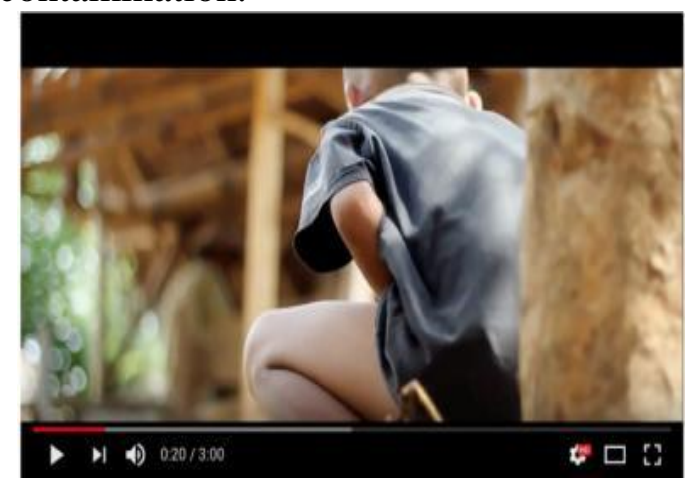

Picture 3. Defecating in the Open, next to Cowshed

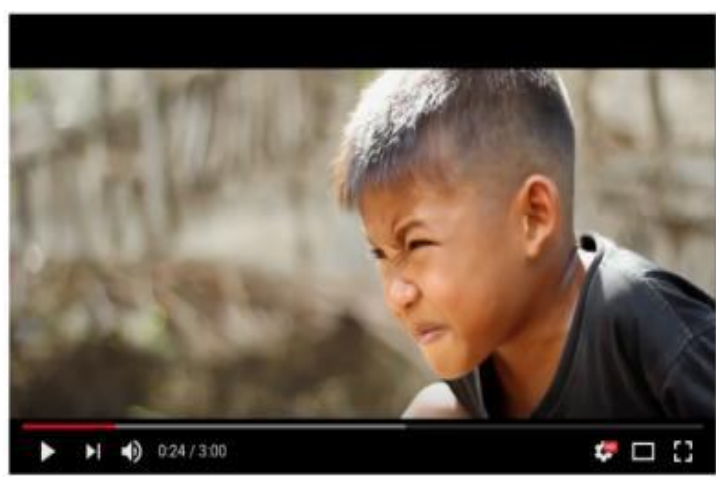

Picture 4. The Expression while Performing Open Defecation

Defecating in the open (picture 3) and such natural expression without a sense of awkwardness (picture 4) within his parents' awareness, receives no reproach at all from the father who is busy feeding the cows, nor from the mother who is complaining about the younger child unceasing cry. The Focus of SaniFOAM here is clear, it is the defecating in the open behavior that need to be changed; and it is the boy who need to change his behavior. Looking at how natural the boy defecates in the open, we wonder if there is an opportunity for the family to stop open-defecation. One dimension of the Opportunity aspect of SaniFOAM is about social norms. In a global review to find out what influences open defecation and latrine ownership in rural households, O'Connell (2014) discovered a number interesting findings about social norms that may explain why people prefer defecating in the open, such as:

"If I defecate in the river, I feel more comfortable. I don't have to smell my own wasteunlike when I'm doing it in a (closed) latrine."

"Yeah, I am embarrassed if people pass by, but I think everybody is used to it, everybody also does that - East Java."

Those honest responses help us understand the context why the boy in the PSA show no peculiar expression at all. District Health Office as the producer of the PSA just presents the social practice of open defecation in rural North Lombok. In West Nusa Tenggara Province, North Lombok District is identified among those with few accesses to sanitation facilities. Despite all 33 villages in the district have adopted the national strategy of 'Sanitasi Total Berbasis Masyarakat'/Community Based Total Sanitation, less than $40 \%$ or only 13 have declared as Open Defecation Free (ODF) villages (Dinas Kesehatan Propinsi Nusa Tenggara Barat, 2018). District-wide data shows nearly $30 \%$ of population do not have adequate sanitation facilities.

The PSA tells us the acceptable social practices of open defecation. However, we cannot see from it unless it is traced to the community's socio-cultural context, in this case the social norms toward such behavior and the absence of social sanctions for those 
performing it. Looking at the boy's parents who seem to be OK with their son defecating in the open, and did not at all reprimand him of this behavior, may explain how another respondent in the same study believes the habits of defecting in the open by which a person was brought up will prompt her or him to do the same in the future.

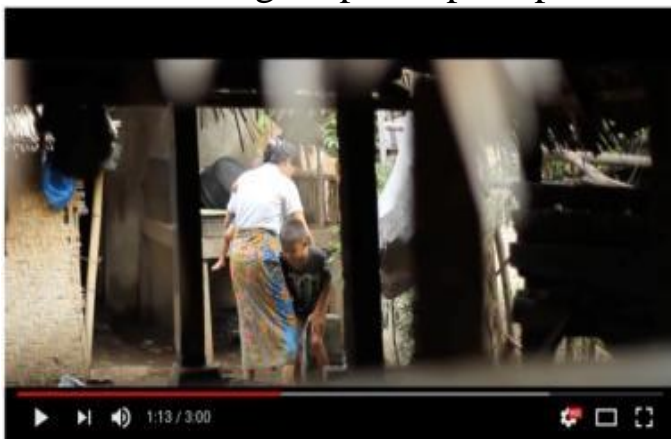

Picture 5. Mother washing her Son after defecation

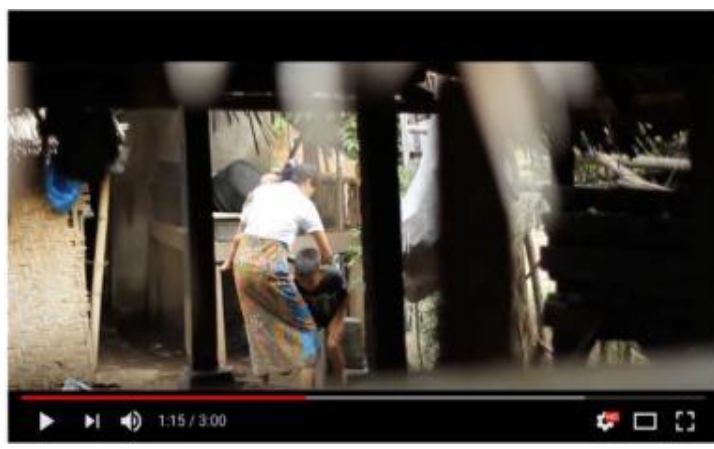

Picture 6. Absence of Handwashing with Soap

After defecating next to the cowshed and the house, the mother offers to wash the son who is already in school-age. While carrying the younger child, the mother washes the son (picture 5 and picture 6). The images show water running to the back of the boy who is half-standing, there is no display of rubbing or the use of soap. Upon washing the son, the mother does not wash her nor her son's hands, although she is carrying the younger child. Not only in North Lombok, handwashing after contact with excreta has not been practiced consciously. Despite the benefits of handwashing in reducing the risk of diarrhea up to $40 \%$, only $19 \%$ of world population who practice this behavior after contact with excreta (Freeman et al., 2014). This underperformed behavior may be related to the Ability component of SaniFOAM, particularly knowledge and skills/efficacy to adequately maintain hand hygiene especially after contact with fecal substances. According to an impact evaluation baseline report on Indonesia nutrition project, handwashing behavior is discussed with women by $75 \%$ of midwives and $58 \%$ 'Posyandu' cadres (Null et al., 2016). Furthermore, the report points out that only 53\% and $31 \%$ midwives and 'Posyandu' cadres respectively demonstrate handwashing with soap to the women they counsel.

Not knowing why the younger child hasn't stop crying and fail to soothe him make the wife annoyed and upset with the husband. Eventually, she requests the husband to look for a shaman and ask why this younger child frequently gets sick (picture 7). Again, the husband ignores the request and continue doing his task feeding the cows (picture 8).

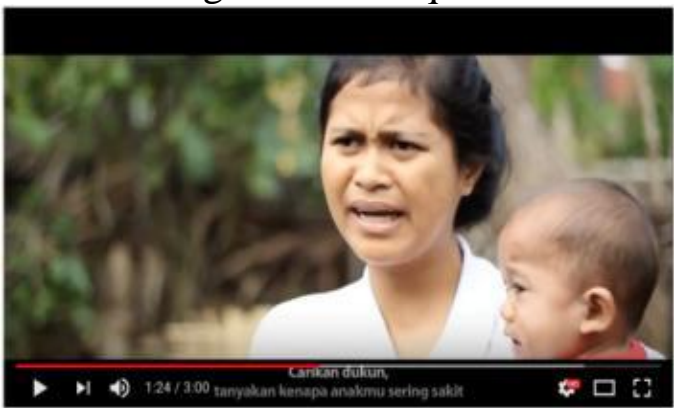

Picture 7. The Wife asking for a Shaman's service

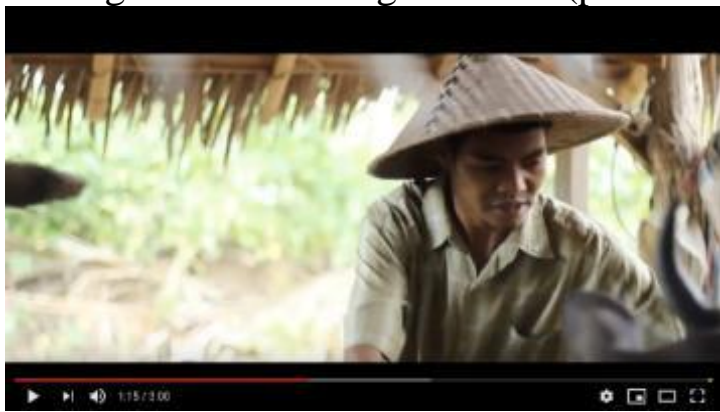

Picture 8. The Husband feeding Cows and ignores the Wife request

This is a significant part of the entire texts of the PSA because it touches at all four aspects of the SaniFOAM framework. As O'Connell (2014) found out, sociodemographic 
and background characteristics of targeted people are among key factors to influence behavior. On the Focus aspect, characteristics of the family in the PSA and the village setting demonstrate face of poverty, while as the mother offers to wash her school-age son after defecating in the open indicates poor parenting skill, especially in cultivating the child's autonomy. On the Opportunity aspect, where using a shaman's service is still a social practice in the community. On the other hand, we may question how health care providers such as midwives are available in that village that the first thing comes into the mother's mind is to seek the help of a shaman.

For the Ability aspect, the text emphasizes lack of knowledge about consequences of poor environment quality to the health of young age children has led the wife to passon the diagnosis - and treatment - of her child's sickness to a shaman. Not sufficient knowledge about the importance of clean environment bears the possibility to neglect environment contamination risk to the child' health. In addition to limited number of health providers, addressing risk behavior is also a challenge. According to Null et al. (2016), less than $15 \%$ of Sanitarian have been trained about handwashing behavior, diarrhea treatment, as well as mother and child nutrition issues.

As for the Motivation aspect, socio analysis points to expression of the mother's lack of beliefs in health-providers' expertise may have driven her to request her husband to look for a shaman. For some rural communities, shamans are reliable in addressing pregnant women and child health issues and consequently gains respectable reputation. A rural community in Lamanggau village in Tolandona island, South-east Sulawesi for example, 'Sandro' -- the local term for shaman -- compensates limited number of village midwives and readily visit pregnant women and children in sickness (Agustiya \& Fitrianti, 2013). Unlike village midwives who visit pregnant women and young children once in a month, 'Sandro' blend in community more frequently, they undertake their social roles smoothly and recognized as being always ready to help.

When introduced to the Sanitarian and the Nutritionist, the mother pours out her concerns about her younger child's health, with a clear emphasis on the body weight. Her main message to the officers is precise: my child is thin, he gets sick frequently. The mother does not mention about nutrition, probably because nutrition status is considered not as important as health status, the mother concerns about the child being sick too often, she is not well-informed on the importance of monitoring nutrition on top of the child's health. The Nutritionist then introduces stunting as a nutrition problem caused by prolonged insufficient nutrition in-take which is reflected in children having short posture. Apparently, stunting is unfamiliar to the couple, seems they just heard the term for the first time. The Sanitarian clarifies that poor environmental health as well leads to stunting. Furthermore, he reminds the couple to boil water for drinking purpose, washing hand with soap, consume nutritious food, and stop defecating in the open. In conclusion, the Sanitarian appeals to audience to maintain cleanliness for better quality of environmental health.

A study conducted in three districts in Indonesia generates a bold conclusion that unimproved sanitation facility and treatment of drinking water are strong predictor of stunting in children below two years old (Torlesse et al., 2016). Unless a sanitation facility is connected to protected and leakage-proof, it is considered unimproved. Torlesse and team also find out severe stunting is significantly higher if the households neglect safe disposal of child feces and do not use soap for handwashing. This definition of improved sanitation underlines the hazard brought by open defecation and failure in maintaining handwashing practices. 
Mothers' knowledge about child nutrition status has been found to be significantly related to the actual nutrition status of the child (Wahyuni, 2009). However, our country is now dealing with community participation in promoting mother and child health. 'Posyandu' as the frontliner in health promotion through preventive and curative strategy seems not as popular as it is expected. Even though 'Posyandu' cadres can help mothers monitoring their children growth on monthly basis, and provide counseling and additional nutritious food when a child requires, not every mother makes use of this service. Referring to Basic Health Research or 'Riskesdas' 2013, Dewi \& Anisa (2018) highlight the decreasing number of mothers who check their infant children's health to 'Posyandu', that only $26 \%$ of households in Bengkulu are aware of 'Posyandu'. On the other hand, 'Posyandu' also have their own struggle in maintaining dedicated and competent cadres. Very few 'Posyandu' are categorized as Mandiri or independent, the most matured class defined as able to operating on-their own. In Lombok Utara, majority of Posyandu has not reach full maturity, only $1.27 \%$ are called 'Mandiri Posyandu' (Dinas Kesehatan Provinsi Nusa Tenggara Barat, 2018). Furthermore, Dewi \& Anisa (2018) found significant correlation between community participation in health services with 'Posyandu' cadres, particularly their credibility, skills, trustworthiness, and attractiveness.

While majority of mothers in rural area may not be aware of the benefits, effort to promote nutrition status monitoring particularly during early childhood has produced expected impact. An experiment study conducted in Jember, East Java concludes that using an android-based application for nutrition status of children under five has notably helped mothers gain knowledge on their children nutrition status (Pratiwi \& Restanty, 2018). Majority of respondents of this study are young mothers having children aged 12 to 24 months and senior high school graduates, indicating they have adequate capacity to absorb new learning about child nutrition status and how to use the application. However, gadget skill has overwhelmed our society as we aware that poverty does not limit households to meet the need to enjoy the technology and stay connected to social media. Therefore, amidst insufficient supply of health providers such as sanitarian and midwives, especially to remote villages, a user-friendly android application and network coverage may be a solution to address outreach coverage challenges in reaching the targeted group of mothers of young children in remote area.

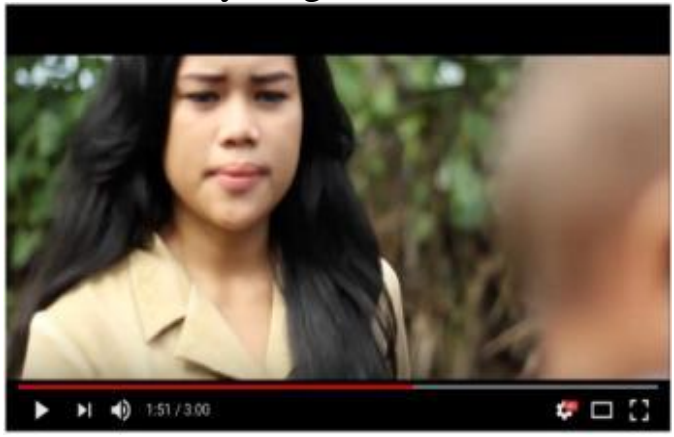

Picture 9. Nutrition Specialist explaining about Stunting

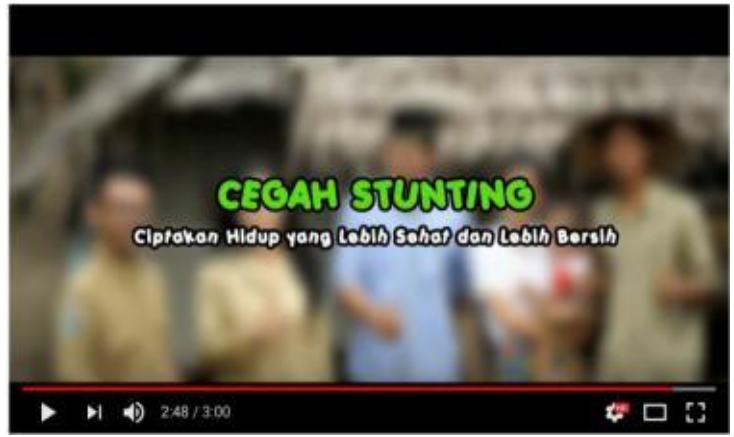

Picture 10. Prevent Stunting through a Healthier and Cleaner Life

Upon conveying main message on risk factors of stunting which include poor environmental health and nutrition in-take, everyone in the PSA appeals audience to prevent stunting in the land of 'Tioq Tata Tunaq' which is the motto of North Lombok District. 
In studying a PSA on the importance of saying 'thank you', researchers concluded that PSA should be developed to suit the group of people targeted to change (Sugoto, Dektisa, \& Cahyadi, 2011). In this sense, District Health Office of North Lombok Regency has done accordingly. However, Shahab (2013) added that effective PSAs should be powerful in bringing cognitive, affective, and behavioral impacts to the targeted people. It may take some time for the local government to watch how effective the PSA in eliminating open defecation practices in North Lombok.

\section{Conclusion}

On the predictive effectiveness, the PSA seems to successfully conveys the government's main messages about stunting, covering the definition, period of time when it is happens, indicators, risk factors. The flow is logically presented, strengthened by some witty probing that immediately followed by understandable confirmation. Both format and duration are clear and entertaining as it shows a lively young family in dayto-day rural context. The PSA's choice to use local language and Head of Sub-village, Sanitarian and Nutrition Specialist as the messengers is powerful one as it targets rural communities where prominent leaders and relevant experts are highly respected.

Critical analysis on this PSA straightly points to open defecation as the behavior that need to be changed by the rural society, that represents the Focus of SaniFOAM. Discourse between the Sanitarian and Nutrition Specialist with the couple appears to emphasize previously presented behavior of defecating in the open as a risk factor to the stunted young child. However, the PSA overlooks handwashing with soap as another targeted behavior that will reduce risk factors for stunting. In terms of Opportunity aspect, the Head of Sub-village may play an important role in introducing new social norms, through an application of social sanctions for open defecation practice. He can also promote sanitation business aiming to help households seeking to build their own latrines as to increase access to safe sanitation facility. As endorsed by the local government of North Lombok, Ability aspect of the behavior change in rural community should start with building knowledge about the risks of inappropriate sanitation behavior and poor environmental health. Followed by social support rendered by community leaders, rural society may improve their confidence and efficacy to stop open defecation and safely dispose children feces. Seeking help from shamans is found to be common, and that reflects rural society's attitudes and beliefs of sometimes disregarding health providers' services. In this regard, shaman can participate in addressing the Motivation aspect, by extending their ordinary services into additional role in educating households to adopt new values and attitudes, particularly in respecting their environment and maintaining better health.

\section{Acknowledgements}

The writers would like to thank Post-Graduate Program of Psychology, UNIKA Atma Jaya for their consistent support, feedback, and guidance in completing this study, especially as our contribution in health psychology perspective to elaborate public health issues nowadays through media communication.

\section{References}

Agustiya, R., \& Fitrianti, Y. (2013). Sandro, Pangullieh dan Bidan dalam Persalinan di Lamanggau. In D. A. Laksono \& T. Rachmawati (Eds.), Determinan. Kanisius.

Almoosawi, S., Jones, A. R., Parkinson, K. N., Pearce, M. S., Collins, H., \& Adamson, 
A. J. (2016). Parental Perception of Weight Status: Influence on Children's Diet in The Gateshead Millennium Study. PLoS ONE, 11(2), 1-14. Retrieved from https://doi.org/10.1371/journal.pone.0144931

Checkley, W., Buckley, G., Gilman, R. H., Assis, A. M., Guerrant, R. L., Morris, S. S., ... Black, R. E. (2008). Multi-country analysis of the effects of diarrhoea on childhood stunting. International Journal of Epidemiology, 37, 816-830. https://doi.org/10.1093/ije/dyn099

Cheng, T. S., Loy, S. L., Cheung, Y. B., Chan, J. K. Y., Tint, M. T., Godfrey, K. M., ... Chan, Y. H. (2016). Singaporean mothers' perception of their three-year-old child's weight status: A cross-sectional study. PLoS ONE, 11(1), 1-15. https://doi.org/10.1371/journal.pone.0147563

Danaei, G., Andrews, K. G., Sudfeld, C. R., Fink, G., McCoy, D. C., Peet, E., ... Fawzi, W. W. (2016). Risk Factors for Childhood Stunting in 137 Developing Countries: A Comparative Risk Assessment Analysis at Global, Regional, and Country Levels. PLoS Medicine, 13(11), 1-18. https://doi.org/10.1371/journal.pmed.1002164

Desyanti, C., \& Nindya, T. S. (2017). Hubungan Riwayat Penyakit Diare dan Praktik Higiene dengan Kejadian Stunting pada Balita Usia 24-59 Bulan di Wilayah Kerja Puskesmas Simolawang, Surabaya. Amerta Nutr, 243-251. Retrieved from https://doi.org/DOI : 10.2473/amnt.v1i3.2017.243-251

Devine, J. (2009). Introducing SaniFOAM: A Framework to Analyze Sanitation Behaviors to Design Effective Sanitation Program.

Dewi, R., \& Anisa, R. (2018). The Influence of Posyandu Cadres Credibility on Community Participation in Health Program. Jurnal The Messenger, 10(1), 83. https://doi.org/10.26623/themessenger.v10i1.596

Dinas Kesehatan Provinsi Nusa Tenggara Barat. (2018). PROFIL KESEHATAN PROVINSI NUSA TENGGARA BARAT TAHUN 2017.

Ellyawati, H. C. (2017). Analisis Wacana Kritis Teks Berita Kasus Terbongkarnya Perlakuan Istimewa terhadap Terpidana Suap Arthalyta Suryani pada Media $\begin{array}{lllll}\text { Online. Jurnal } & \text { 3(2), }\end{array}$ https://doi.org/10.26623/themessenger.v3i2.267

Freeman, M. C., Stocks, M. E., Cumming, O., Jeandron, A., Higgins, J. P. T., Wolf, J., ... Curtis, V. (2014). Systematic review: Hygiene and health: Systematic review of handwashing practices worldwide and update of health effects. Tropical Medicine and International Health, 19(8), 906-916. https://doi.org/10.1111/tmi.12339

García Cruz, L. M., González Azpeitia, G., Reyes Súarez, D., Santana Rodríguez, A., Loro Ferrer, J. F., \& Serra-Majem, L. (2017). Factors associated with stunting among children aged 0 to 59 months from the central region of Mozambique. Nutrients, 9(5), 1-16. Retrieved from https://doi.org/10.3390/nu9050491

George, C. M., Oldja, L., Biswas, S., Perin, J., Lee, G. O., Kosek, M., ... Faruque, A. G. (2015). Geophagy is associated with environmental enteropathy and stunting in children in rural Bangladesh. American Journal of Tropical Medicine and Hygiene, 92(6), 1117-1124. https://doi.org/10.4269/ajtmh.14-0672

George, C. M., Oldja, L., Perin, J., Sack, R. B., Biswas, S., Ahmed, S., ... Faruque, A. G. (2016). Unsafe Child Feces Disposal is Associated with Environmental Enteropathy and Impaired Growth. Journal of Pediatrics. https://doi.org/10.1016/j.jpeds.2016.05.035

Hastuti, S. (2013). Efektivitas iklan layanan masyarakat di televisi. Jurnal Ilmu Komunikasi, 2(2), 67-72. 
Kementerian Kesehatan. (2018). HASIL PEMANTAUAN STATUS GIZI (PSG) TAHUN 2017.

Mbuya, M. N. N., \& Humphrey, J. H. (2016). Preventing environmental enteric dysfunction through improved water, sanitation and hygiene: An opportunity for stunting reduction in developing countries. The Lancet. https://doi.org/10.1111/mcn.12220

MCA-I. (2015). Memahami Perilaku Masyarakat Indonesia tentang Gizi dan Kebersihan.

MCA Indonesia. (2014). Community-Based Health and Nutrition to Reduce Stunting Project.

Null, C., Beatly, A., Ingwersen, N., Leith, W., Borkum, E., Haimson, J. B., ... Rangarajan, A. (2016). MCC Indonesia Nutrition Project Impact Evaluation Baseline Report.

O'Connell, K. (2014). What Influences Open Defecation and Latrine Ownership in Rural Households?

Omrow, D. A. (2018). It is not easy being green: A critical discourse and frame analysis of environmental advocacy on American television. Journal of Media and Communication Studies, 10(3), 14-24. Retrieved from https://doi.org/10.5897/jmcs2018.0609

Park, S. H. (2017). Asian Parents' Perception of Child Weight Status: A Systematic Review. Journal of Child and Family Studies, 26(9), 2363-2373. https://doi.org/10.1007/s10826-017-0765-x

Pratiwi, I. G., \& Restanty, D. A. (2018). Penerapan Aplikasi Berbasis Android "Status Gizi Balita Terhadap Pengetahuan Ibu Dalam Pemantauan Status Gizi Anak Usia 12-24 Bulan." Jkakj, 2(1), 8-14.

Remmers, T., Van Grieken, A., Renders, C. M., Hirasing, R. A., Broeren, S. M. L., \& Raat, H. (2014). Correlates of parental misperception of their child's weight status: The "be active, eat right" study. PLoS ONE, 9(2). https://doi.org/10.1371/journal.pone.0088931

Setiawan, Y. B., \& Fanani, F. (2017). BKKBN JAWA TENGAH UNDERSTANDING CENTRAL JAVA BKKBN DISCOURSE ON THEIR. Jurnal The Mesenger, 9, 44-54.

Shahab, M. R. (2013). Studi Efek Iklan Layanan Masyarakat Tentang anjuran Membayar Pajak Melalui TVRI KALTIM. EJournal Ilmu Komunikasi, 1(2), 311-323.

Spears, D. (2013). How Much International Variation in Child Height Can Sanitation Explain?

Stephen W, L., \& Karen A, F. (2009). Encyclopedia of Communication Theory.

Sugoto, M., Dektisa, A., \& Cahyadi, J. (2011). Kajian Iklan Layanan Masyarakat Tentang Pentingnya Mengucapkan Terima Kasih Bagi Para Remaja Di Surabaya. Nirmana, 11(2). https://doi.org/https://doi.org/10.9744/nirmana.11.2.pp.\%20106-113

Torlesse, H., Cronin, A. A., Sebayang, S. K., \& Nandy, R. (2016). Determinants of stunting in Indonesian children: Evidence from a cross-sectional survey indicate a prominent role for the water, sanitation and hygiene sector in stunting reduction. BMC Public Health, 16(1), 1-11. https://doi.org/10.1186/s12889-016-3339-8

Ulinnuha, R. (2015). Critical Discourse Analysis: Theory and Method in Social and Literary Framework. Indonesian Journal of Applied Linguistics, 2(2), 262. https://doi.org/10.17509/ijal.v2i2.170

Wahyuni, I. S. (2009). Hubungan Tingkat Pengetahuan Ibu tentang Gizi dengan Status 
Gizi Anak Balita di Desa Ngemplak Kecamatan Karangpandan Kabupaten Karanganyar. https://doi.org/10.2174/138920312803582960

WHO, UNICEF, \& USAID. (2015). Improving Nutrition Outcomes with Better Water, Sanitation, and Hygiene. Retrieved from https://www.who.int/water_sanitation_health/publications/washandnutrition/en/ 